\title{
Dietary Supplements for Lactating Goats by Polyunsaturated Fatty Acid-Rich Protected Fat. Effects After Supplement Withdrawal
}

\author{
M. R. Sanz Sampelayo, J. J. Martín Alonso, L. Pérez, \\ F. Gil Extremera, and J. Boza \\ Consejo Superior de Investigaciones Científicas \\ Estación Experimental del Zaidín \\ Unidad de Nutrición Animal \\ Profesor Albareda, 1. 18008 Granada, Spain
}

\begin{abstract}
The objective of this study was to investigate the persistence of the effects of supplements after they were withdrawn. Two groups of 12 goats were maintained under semiextensive breeding conditions; they were fed indoors with a concentrate with alfalfa hay and olivetree leaves. Goats were in their sixth month of lactation at initiation of the study. During the first month of the trials, the concentrate supplied to the goats was either nonsupplemented (group 1) or supplemented with 9\% polyunsaturated fatty acids (PUFA)-rich protected fat (group 2). After this period, the 2 groups were given the nonsupplemented until the average daily production of milk per animal within each group had decreased to $300 \mathrm{~g}$ or less. The fat supplementation supplied increased milk production and also improved fat and protein yield. These effects persisted after the supplement was withdrawn. The supplement, moreover, produced noticeable changes in the fatty acids profile of the milk fat, namely a reduction in the concentration of saturated fatty acids and an increase in that of PUFA. In contrast to the effects on milk production and on the yield of its main constituents, the effects on fat composition disappeared when the supplement was withdrawn. (Key words: lactating goat, polyunsaturated fatty acid-rich protected fat, supplementation, effects after supplement withdrawal)
\end{abstract}

Abbreviation key: PUFA = polyunsaturated fatty acids.

\section{INTRODUCTION}

Goat milk, like that of any ruminant, contains a high proportion of saturated fats, the consumption of which

Received May 5, 2003.

Accepted December 1, 2003.

Corresponding author: M. R. Sanz Sampelayo; e-mail: rsanz@ eez.csic.es. is considered a risk factor for cardiovascular disease (Ney, 1991). Polyunsaturated fatty acids (PUFA), which have been associated with a reduction in the above risk factor, were shown to be relatively scarce in milk fats (Daviglus et al., 1997, Albert et al., 1998). When a ruminant consumes a fat-supplemented diet, the fatty acids are soon detectable in the animal's serum and subsequently form part of its milk fat (Ashes et al., 1992; Franklin et al., 1999). Consequently, attempts have been made to alter the composition of cow milk fat to make it more suitable for human consumption (Grummer, 1991, Ashes et al., 1997, Franklin et al., 1999) by introducing different types of protected fats into the diet. At the same time, depending on the level of supplementation supplied and on the quantity of food consumed, other effects are produced, concerning the quantity of milk produced and its composition (Jenkins and Palmquist, 1984; Gagliostro and Chilliard, 1992). When the diet of lactating goats was supplemented with a ruminant metabolism-protected fat that was particularly rich in PUFA, both milk production and the PUFA content of milk fat increased (Sanz Sampelayo et al., 2000). On the basis of these results, the objective of the present study was to investigate the persistence of these effects once such a diet supplement is withdrawn. To the best of our knowledge, this is the first published research on this subject. In our opinion, the results of such a study would be useful in designing animal-fed supplementation strategies aimed at obtaining milk of a more desirable composition.

\section{MATERIALS AND METHODS}

\section{Experimental Design and Procedure}

Twenty-four Granadina goats were used from a farm typical of southeast Spain, in which both livestock and crops are produced (specifically, olives, cereal crops, and goats). The animals were divided into 2 homogeneous groups, depending on their lactation (first to third), milk production, and body condition. For the latter, based 
Table 1. Ingredient composition of the concentrates and chemical composition and gross energy content of the concentrates, alfalfa hay and olive tree leaf.

\begin{tabular}{|c|c|c|c|c|}
\hline \multirow[b]{2}{*}{ Ingredients } & \multicolumn{2}{|c|}{ Concentrate $^{1}$} & \multirow{2}{*}{$\begin{array}{l}\text { Alfalfa } \\
\text { hay }\end{array}$} & \multirow{2}{*}{$\begin{array}{l}\text { Olive tree } \\
\text { leaf }\end{array}$} \\
\hline & 1 & 2 & & \\
\hline & $\longrightarrow$ & $\longrightarrow$ & & \\
\hline Lupinus & 280 & 236 & & \\
\hline Oats & 480 & 405 & & \\
\hline Corn & 150 & 127 & & \\
\hline Sunflower seeds & 50 & 42 & & \\
\hline Protected fat & - & 150 & & \\
\hline Mineral and vitamin complement & 40 & 40 & & \\
\hline \multicolumn{5}{|c|}{ Chemical composition and gross energy content } \\
\hline \multirow[t]{2}{*}{$\mathrm{DM}, \%$} & 88.54 & 88.87 & 89.74 & 63.00 \\
\hline & \multicolumn{2}{|c|}{$-\%$ of $\mathrm{DM}-$} & & \\
\hline $\mathrm{OM}$ & 91.10 & 89.41 & 87.77 & 86.45 \\
\hline $\mathrm{CP}$ & 19.93 & 17.22 & 21.06 & 7.00 \\
\hline Fat & 5.69 & 13.92 & 0.99 & 3.21 \\
\hline $\mathrm{NDF}$ & 23.09 & 21.72 & 40.59 & 41.48 \\
\hline $\mathrm{ADF}$ & 12.66 & 9.90 & 32.69 & 27.93 \\
\hline Acid detergent lignin & 1.89 & 1.81 & 6.86 & 16.55 \\
\hline Gross energy, MJ/kg of DM & 19.3 & 20.3 & 17.7 & 16.8 \\
\hline
\end{tabular}

${ }^{1}$ Concentrates 1 and 2 with 0 and $9 \%$ of polyunsaturated fatty acid-rich protected fat.

on a 3-point scale from 1 (thin) to 3 (fat), the body condition of the animals selected at the start of the present study corresponded to 2 . The study began 5 mo after the start of the corresponding lactation for each animal. The animals were maintained under semiextensive breeding conditions, being indoor fed with a concentrate ( $1 \mathrm{~kg}$ per animal and day), together with alfalfa hay and olive-tree leaves ad libitum. Water was available at all times. As the trials were carried out during the autumn months, the food available to the goats in the open comprised mainly stubble field, so not only concentrate but also fodder had to be provided indoors. Every day at 9:00 a.m., the goats were handmilked and then allowed to graze within the farm for $4 \mathrm{~h}$. During the first month of the trials, the concentrate consumed by the animals was nonsupplemented, in the case of group 1, or supplemented with 9\% PUFA-rich protected fats (the calcium salts of the corresponding fatty acids), in the case of group 2 . The protected fat was obtained and stabilized following the protocol designed by Boza et al. (2000). The quantity of protected fat included in the supplementation concentrate replaced an equal weight-for-weight quantity of the basal concentrate mix except for that corresponding to the mineral-vitamin supplement. The ingredients of the concentrates, their chemical composition, and that of the alfalfa hay and the olive tree leaves are shown in Table 1.

The animals in group 2 were allowed about $10 \mathrm{~d}$ to adapt gradually to consuming the fat-supplemented concentrate. Then milk production and composition were recorded for both groups, twice a week for $3 \mathrm{wk}$.
After this period, all the goats were fed with the nonsupplemented concentrate, with the milk production and composition being recorded as before until the average production per animal per day within each group was equal to or less than $300 \mathrm{~g}$. At the end of the experimental period, the body condition of the animals was again recorded. The intake of DM could not be quantified because of the type of trials carried out, and the consumption of concentrate by each group was inspected daily throughout the experimental period.

\section{Preparation of the Fat Supplement and Its Composition}

The original fat was of marine origin, fish oil rich in PUFA, especially of the n-3 series. The calcium salts of its fatty acids were prepared according to the doubledecomposition method described by Jenkins and Palmquist (1984). A solution of sodium hydroxide in a waterethanol mixture was added to the fat that was previously heated. This way, the soluble sodium salts of the different fatty acids were obtained. After this, an excess of calcium chloride solution was added, which provoked the precipitation of the calcium salts of the different fatty acids. Finally, the excess liquid was separated by filtering and by compression. The calcium salts obtained were air-dried, pulverized, and mixed with other components of the concentrate. Details of the different phases of the process described have been published in Boza et al. (2000). The chemical composition of the protected fat is given in Table 2. The degree of saponification of the latter, which in this case was equal 
Table 2. Chemical composition of the protected fat.

\begin{tabular}{lr}
\hline DM $(\%)$ & \\
DM composition (\%) & \\
HCl fat & 70.6 \\
Ether extract & 10.7 \\
Fatty acid composition (\%) of fat & \\
C14:0 & 5.16 \\
C15:0 & 0.64 \\
C16:0 & 21.73 \\
C16:1 & 6.90 \\
C17:0 & 0.59 \\
C18:0 & 4.16 \\
C18:1 & 24.12 \\
C18:2 & 1.41 \\
C20:0 & 6.62 \\
C20:2 & 0.22 \\
C20:3 & 0.22 \\
C20:4 & 0.83 \\
C20:5 & 0.61 \\
C22:0 & 6.45 \\
C22:6 & 5.09 \\
\end{tabular}

to $84.8 \%$, was considered to be equal to the amount of fat not extracted without previous acid hydrolysis (Hermansen and Lund, 1990).

\section{Feedstuffs and Milk Sample Analysis}

The DM and $\mathrm{N}$ contents of the feedstuffs were analyzed in fresh samples. All other analyses were performed on dried samples. The DM of the feedstuffs was determined by oven-drying at $100 \pm 2^{\circ} \mathrm{C}$ for $24 \mathrm{~h}$. The $\mathrm{N}$ content was measured using the Kjeldahl method (AOAC, 1975). The results were converted to $\mathrm{CP}$ by multiplying $\mathrm{N}$ by a factor of 6.25 . The NDF, ADF, and acid detergent lignin contents of these samples were determined using the method of Van Soest et al. (1991). Fat was measured by extraction with petroleum ether (boiling point, 40 to $60^{\circ} \mathrm{C}$ ) and the ash content by incineration in an electric muffle furnace at $550^{\circ} \mathrm{C}$. Finally, the energy content of the samples was determined by adiabatic bomb calorimetry.

Throughout the study, 3 aliquots of milk were obtained from each animal twice a week. One portion was analyzed for contents of fat and different $\mathrm{N}$ fractions. A second portion was used to determine total solids content. The third portion was stored at $-30^{\circ} \mathrm{C}$ for later analysis of fatty acid profile. The total solids content was determined by lyophilization and the $\mathrm{N}$ content by the Kjeldahl methods (AOAC, 1975). The true protein $\mathrm{N}$ content of the milk samples was calculated as the difference between total N and NPN; total N was determined from whole milk samples and NPN from filtrates of whole milk after precipitation with $12 \%$ (wt/vol) TCA (Martin-Hernandez et al., 1988). Protein $\mathrm{N}$ values were converted to protein by multiplying by a factor of 6.38 .
Fat content was measured by the Gerber method (Pearson, 1976).

To determine the fatty acid composition of the milk fat, the fatty acid methyl esters were separated on an autosystem gas chromatograph (Perkin-Elmer Corp., Norwalk, CT) with a SP-2330 capillary column (60 m $\times 0.032 \mathrm{~mm}$ i.d.; Supelco, Bellefonte, PA) equipped with a flame-ionization detector. The temperature was programmed from 60 to $70^{\circ} \mathrm{C}$ at $2^{\circ} \mathrm{C} / \mathrm{min}$ and from 70 to $230^{\circ} \mathrm{C}$ at $20^{\circ} \mathrm{C} / \mathrm{min}$. The carrier gas was He. Injector and detector temperatures were 230 and $250^{\circ} \mathrm{C}$, respectively.

\section{Statistical Procedure}

Statistical analysis was performed using methods of the SAS Institute (1987). Effects of the animal group (supplemented and nonsupplemented at the beginning of the trials, respectively) and sampling time and the difference between factor interactions were tested by repeated ANOVA measures with a nested design. When the effect of interaction was not significant $(P>0.05)$, the least square means were calculated from the model omitting this term (Steel and Torrie, 1984).

\section{RESULTS AND DISCUSSION}

The objective was to investigate the persistence of the effects on goat milk production and composition when the animals were fed a diet supplemented with a PUFA-rich protected fat.

Food intake could not be measured in the present trials, and so data concerning the energy balance of the animals cannot be provided. Nevertheless, we attempted to estimate this on the basis of the changes observed in the body condition of the animals. These observations at the start and finish of the trials revealed no significant differences in the animals' body condition. In addition to these observations, a daily record was made of the consumption of the concentrate within each group, calculated from the quantity of feed left in the trough, a quantity found to be always minimal or nonexistent.

\section{Quantity and Composition of Milk Produced}

Figure 1A shows the daily production of milk achieved by each group. For group 2, the figure also shows the final 3 sets of values obtained for this group alone. With regard to the milk production established a priori as coinciding with the end of lactation $(300 \mathrm{~g}$ per animal and day), the animals that initially received the supplemented concentrate (group 2) took $10 \mathrm{~d}$ longer to achieve this quantity of milk production, and thus 

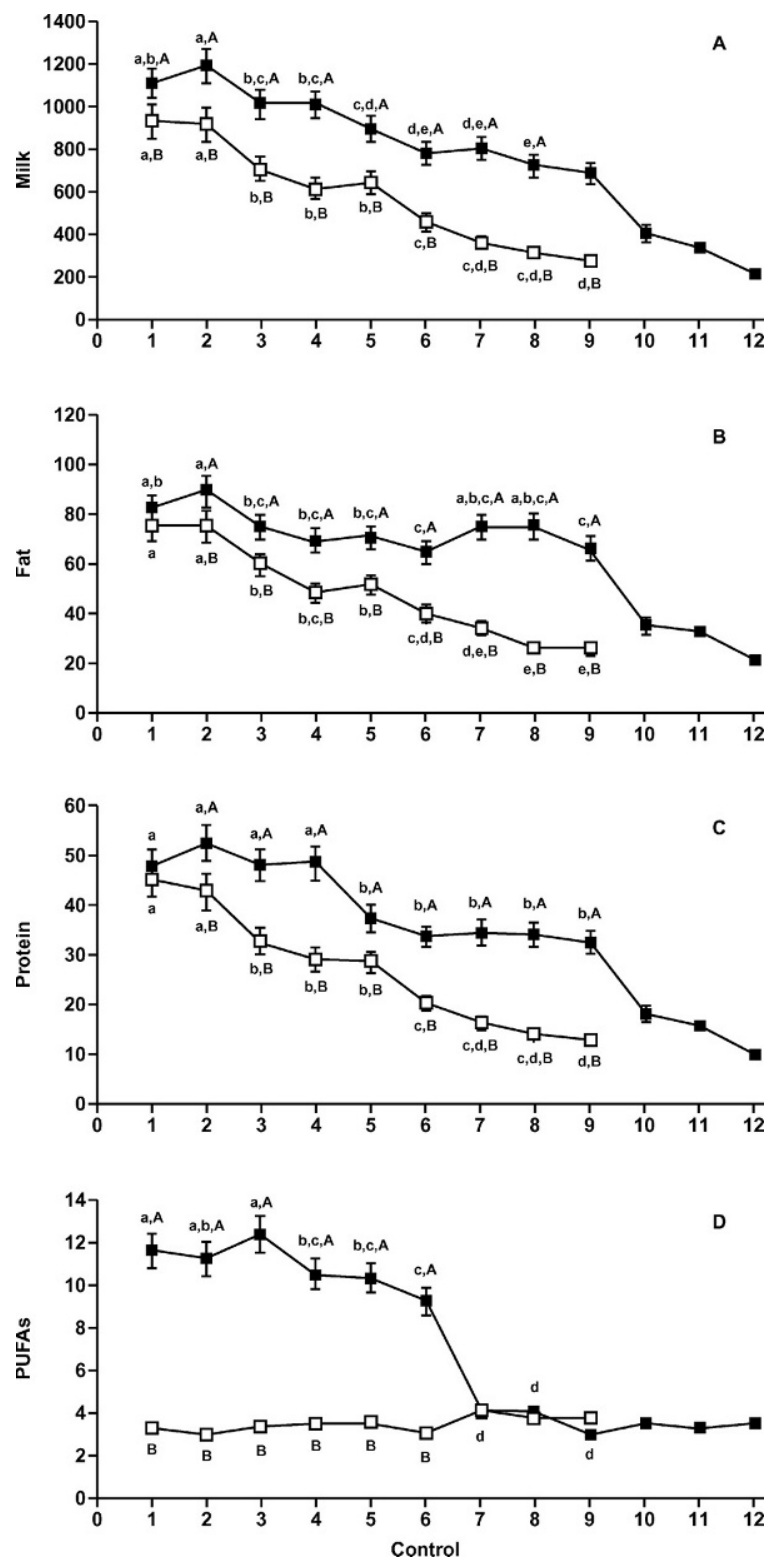

Figure 1. Milk production (g/d) A), fat yield (g/d) B), protein yield (g/d) C), and concentration (\%) of polyunsaturated fatty acid (PUFA) in the milk fat D) of goats fed a non-supplemented concentrate ( $\square$ ) or a concentrate supplemented with a PUFA-rich protected fat (ם). The animals in the supplemented concentrate group, after a period of adaptation to the concentrate (the first $10 \mathrm{~d}$ ), consumed it for a further $3 \mathrm{wk}$ (controls 1 to 6 ). Subsequently, all the animals were fed the nonsupplemented concentrate. They were hand-milked every day until the mean milk production within each group was equal to or less than $300 \mathrm{~g} / \mathrm{d}$. The production and composition of the milk was measured twice a week (controls). ${ }^{\mathrm{A}, \mathrm{B}}$ Within the same control, the mean values affected by different letters are different $(P<0.05)$. $\mathrm{a}, \mathrm{b}, \mathrm{c}, \mathrm{d}, \mathrm{e}$ Within the same group, the mean values affected by different letters are different $(P<0.05)$. For the yields of fat and protein and the concentration of PUFA in the milk fat, it was observed a significant interaction $(P<0.05)$ between experimental group $\times$ control (pooled $\mathrm{RSD}=139.9,10.9,6.4$, and 1.1 for milk production, fat yield, protein yield, and PUFA concentration in the milk fat, respectively). Error bars not shown are smaller than the symbols. the supplement had a positive effect on the duration of lactation. The same figure shows the effects on milk production by the 2 factors involved (sampling time and experimental group) during the period in which both groups of animals were milked. The daily quantity of milk produced was affected by the 2 factors involved $(P<0.05)$, although the interaction between them was not significant $(P>0.05)$. The quantity of milk produced by the goats in group 2 was always higher than the corresponding value for the group 1 animals. As lactation advanced, smaller quantities of milk were produced by both groups, and differences were observed $(P<0.05)$ between the values corresponding to the first 4 sampling times with respect to the final 3 . When the ruminants' diet is supplemented with a protected fat, the first effect that normally occurs if consumption is not negatively affected is of an increase in milk production (Pérez Hernández et al., 1986; Gagliostro and Chilliard, 1992; Brown-Crowder et al., 1996). This seems to be due to the greater energy density presented by the supplemented diet. In the ruminant, milk production is fundamentally determined by the animals' energy balance, a factor that in the goat is of even greater importance than aspects related to characteristics of the diet (Giger et al., 1987; Sauvant et al., 1987; Sanz Sampelayo et al., 1998). Thus it can be deduced that in our trials and for the group 2 animals, the supplementation gives rise to a more positive energy balance. Nevertheless, significant changes were not observed in the body condition of the experimental goats, which might be ascribed to the difficulty in measuring the latter because of their poorly developed subcutaneous adipose deposits (Morand-Fehr, 1997). It is also necessary to take into account that when the ruminant diet is supplemented with fats, a greater efficiency is achieved in the use of the metabolizable energy for milk production (Holter et al., 1992; Schauff et al., 1992; Sanz Sampelayo et al., 2002). The fact that when the fat supplement was withdrawn the animals continued to produce more milk than the control group might be at least partly due to a prolongation of the above-mentioned change in efficiency.

The yields of both the fat and the protein reflect a significant effect $(P<0.05)$ of the 2 factors, in addition to a significant interactive effect $(P<0.05)$ between them (Figure 1B and C). Except in the first sampling time, the fat and protein yields of group 2 were higher than those of group 1 . The yields corresponding to the first measurements obtained for both groups were higher than those subsequently obtained. Within group 2 , there was no additional fall when the food supplement was withdrawn; indeed, within this group the values were even higher when the supplement was removed (sampling times 7 and 8), although the differ- 


\begin{tabular}{|c|c|c|c|c|c|c|c|c|c|c|c|c|c|c|}
\hline & \multirow[b]{2}{*}{ Group } & \multicolumn{9}{|c|}{ Control $^{1}$} & \multirow[b]{2}{*}{$\mathrm{RSD}^{2}$} & \multicolumn{3}{|c|}{ Level of significance } \\
\hline & & 1 & 2 & 3 & 4 & 5 & 6 & 7 & 8 & 9 & & Group (G) & Control (C) & $\mathrm{G} \times \mathrm{C}$ \\
\hline \multirow[t]{2}{*}{ C6:0 } & 1 & 4.25 & 4.28 & 4.19 & 4.29 & 4.58 & 4.19 & 4.40 & 4.49 & 4.42 & 0.95 & $\mathrm{NS}^{3}$ & NS & $\mathrm{NS}$ \\
\hline & 2 & 3.83 & 4.60 & 4.28 & 4.61 & 4.42 & 4.45 & 3.96 & 4.13 & 4.13 & & & & \\
\hline \multirow[t]{2}{*}{ C8:0 } & 1 & 3.93 & 3.99 & 3.85 & 4.04 & 4.30 & 3.78 & 4.16 & 4.19 & 4.03 & 1.11 & NS & NS & NS \\
\hline & 2 & 3.86 & 4.43 & 3.94 & 4.49 & 4.23 & 4.37 & 3.56 & 3.98 & 3.75 & & & & \\
\hline \multirow[t]{2}{*}{ C10:0 } & 1 & 10.55 & 10.80 & 9.47 & 10.47 & 10.61 & 9.87 & 9.97 & 11.71 & 10.76 & 2.17 & NS & NS & NS \\
\hline & 2 & 9.66 & 10.77 & 9.40 & 11.02 & 10.28 & 10.16 & 9.58 & 10.99 & 10.43 & & & & \\
\hline \multirow[t]{2}{*}{ C12:0 } & 1 & 3.83 & 3.91 & 3.99 & 4.28 & 4.27 & 3.49 & 4.24 & 4.04 & 3.68 & 1.34 & NS & NS & NS \\
\hline & 2 & 3.41 & 4.16 & 3.71 & 4.45 & 4.03 & 3.83 & 3.40 & 4.20 & 4.43 & & & & \\
\hline \multirow[t]{2}{*}{ C14:0 } & 1 & $9.43^{\mathrm{a}, \mathrm{b}, \mathrm{c}}$ & $8.50^{\mathrm{a}, \mathrm{A}}$ & $9.26^{\mathrm{a}, \mathrm{b}, \mathrm{A}}$ & $9.64^{\mathrm{a}, \mathrm{b}, \mathrm{c}, \mathrm{A}}$ & $10.28^{\mathrm{b}, \mathrm{c}, \mathrm{A}}$ & $8.67^{\mathrm{a}}$ & $10.34^{\mathrm{c}}$ & $10.08^{\mathrm{b}, \mathrm{c}}$ & $9.67^{\mathrm{a}, \mathrm{b}, \mathrm{c}}$ & 1.62 & $* * *$ & NS & $*$ \\
\hline & 2 & $8.80^{\mathrm{a}, \mathrm{b}}$ & $7.49^{\mathrm{a}, \mathrm{B}}$ & $7.43^{\mathrm{a}, \mathrm{B}}$ & $7.85^{\mathrm{a}, \mathrm{B}}$ & $7.68^{\mathrm{a}, \mathrm{B}}$ & $7.64^{\mathrm{a}}$ & $9.37^{\mathrm{b}}$ & $10.03^{\mathrm{b}}$ & $9.23^{\mathrm{b}}$ & & & & \\
\hline \multirow[t]{2}{*}{ C14:1 } & 1 & $0.26^{\mathrm{a}, \mathrm{A}}$ & $0.60^{\mathrm{c}, \mathrm{A}}$ & $0.47^{\mathrm{b}, \mathrm{A}}$ & $0.49^{\mathrm{b}, \mathrm{A}}$ & $0.74^{\mathrm{d}, \mathrm{A}}$ & $0.47^{\mathrm{b}, \mathrm{A}}$ & $0.29^{\mathrm{a}, \mathrm{A}}$ & $0.72^{\mathrm{d}}$ & $0.72^{\mathrm{d}}$ & 0.12 & $* * *$ & $* * *$ & $* * *$ \\
\hline & 2 & $0.64^{\mathrm{a}, \mathrm{b}, \mathrm{B}}$ & $0.74^{\mathrm{b}, \mathrm{B}}$ & $0.69^{\mathrm{a}, \mathrm{b}, \mathrm{B}}$ & $0.76^{\mathrm{b}, \mathrm{B}}$ & $0.65^{\mathrm{a}, \mathrm{b}, \mathrm{B}}$ & $0.85^{\mathrm{b}, \mathrm{B}}$ & $1.09^{\mathrm{c}, \mathrm{B}}$ & $0.58^{\mathrm{a}}$ & $0.56^{\mathrm{a}}$ & & & & \\
\hline \multirow[t]{2}{*}{ C16:0 } & 1 & 23.74 & 24.69 & 24.10 & 25.77 & 24.09 & 25.14 & 26.34 & 24.58 & 23.25 & 4.75 & NS & NS & NS \\
\hline & 2 & 24.65 & 25.80 & 23.79 & 24.75 & 25.58 & 25.20 & 23.64 & 24.50 & 27.54 & & & & \\
\hline \multirow[t]{2}{*}{ C16:1 } & 1 & $1.38^{\mathrm{a}, \mathrm{A}}$ & $1.46^{\mathrm{a}, \mathrm{b}, \mathrm{c}, \mathrm{A}}$ & $1.44^{\mathrm{a}, \mathrm{b}, \mathrm{A}}$ & $1.50^{\mathrm{a}, \mathrm{b}, \mathrm{c}, \mathrm{A}}$ & $1.64^{\mathrm{a}, \mathrm{b}, \mathrm{c}, \mathrm{d}}$ & $1.68^{\mathrm{b}, \mathrm{c}, \mathrm{d}}$ & $1.99^{\mathrm{e}}$ & $1.76^{\mathrm{c}, \mathrm{d}, \mathrm{e}}$ & $1.83^{\mathrm{d}, \mathrm{e}}$ & 0.31 & $* *$ & * & $*$ \\
\hline & 2 & $1.96^{\mathrm{b}, \mathrm{c}, \mathrm{B}}$ & $2.27^{\mathrm{d}, \mathrm{B}}$ & $2.18^{\mathrm{c}, \mathrm{d}, \mathrm{B}}$ & $1.73^{\mathrm{a}, \mathrm{b}, \mathrm{B}}$ & $1.79^{\mathrm{a}, \mathrm{b}}$ & $1.83^{\mathrm{a}, \mathrm{b}}$ & $1.92^{\mathrm{a}, \mathrm{b}, \mathrm{c}}$ & $1.86^{\mathrm{a}, \mathrm{b}}$ & $1.65^{\mathrm{a}}$ & & & & \\
\hline \multirow{2}{*}{ C18:0 } & $\overline{1}$ & $10.78^{\mathrm{a}, \mathrm{b}, \mathrm{A}}$ & $10.67^{\mathrm{a}, \mathrm{b}, \mathrm{A}}$ & $11.00^{\mathrm{a}, \mathrm{b}, \mathrm{A}}$ & $10.23^{\mathrm{a}, \mathrm{b}, \mathrm{A}}$ & $12.56^{\mathrm{c}, \mathrm{A}}$ & $10.83^{\mathrm{a}, \mathrm{b}, \mathrm{A}}$ & $10.41^{\mathrm{a}, \mathrm{b}}$ & $9.76^{\mathrm{a}}$ & $11.68^{\mathrm{b}, \mathrm{c}}$ & 1.66 & $* * *$ & $* * *$ & $* * *$ \\
\hline & 2 & $7.72^{\mathrm{c}, \mathrm{d}, \mathrm{B}}$ & $5.43^{\mathrm{a}, \mathrm{B}}$ & $7.78^{\mathrm{c}, \mathrm{d}, \mathrm{B}}$ & $5.71^{\mathrm{a}, \mathrm{b}, \mathrm{B}}$ & $6.63^{\mathrm{a}, \mathrm{b}, \mathrm{c}, \mathrm{B}}$ & $7.23^{\mathrm{b}, \mathrm{c}, \mathrm{d}, \mathrm{B}}$ & $11.06^{\mathrm{e}}$ & $8.59^{d}$ & $11.36^{\mathrm{e}}$ & & & & \\
\hline \multirow[t]{2}{*}{ C18:1 } & 1 & 28.47 & 28.11 & 28.93 & 25.96 & 23.37 & 29.54 & 23.30 & 24.88 & 25.95 & 7.24 & NS & NS & NS \\
\hline & 2 & 23.81 & 22.95 & 24.35 & 24.05 & 24.32 & 24.10 & 28.40 & 26.76 & 23.33 & & & & \\
\hline \multirow{2}{*}{ C18:2 } & 1 & $2.45^{\mathrm{a}, \mathrm{b}, \mathrm{A}}$ & $2.29^{\mathrm{a}, \mathrm{A}}$ & $2.34^{\mathrm{a}, \mathrm{b}, \mathrm{A}}$ & $2.47^{\mathrm{a}, \mathrm{b}, \mathrm{A}}$ & $2.62^{\mathrm{a}, \mathrm{b}, \mathrm{c}, \mathrm{A}}$ & $2.27^{\mathrm{a}, \mathrm{A}}$ & $2.32^{\mathrm{a}, \mathrm{b}}$ & $2.65^{\mathrm{b}, \mathrm{c}}$ & $2.87^{\mathrm{c}, \mathrm{A}}$ & 0.40 & $* * *$ & *** & $* * *$ \\
\hline & 2 & $1.71^{\mathrm{a}, \mathrm{B}}$ & $1.64^{\mathrm{a}, \mathrm{B}}$ & $1.86^{\mathrm{a}, \mathrm{B}}$ & $1.51^{\mathrm{a}, \mathrm{B}}$ & $1.51^{\mathrm{a}, \mathrm{B}}$ & $1.50^{\mathrm{a}, \mathrm{B}}$ & $2.62^{\mathrm{b}}$ & $2.56^{\mathrm{b}}$ & $2.36^{\mathrm{b}, \mathrm{B}}$ & & & & \\
\hline \multirow[t]{2}{*}{ C18:3 } & 1 & $0.59^{\mathrm{a}, \mathrm{A}}$ & $0.44^{\mathrm{a}, \mathrm{A}}$ & $0.52^{\mathrm{a}, \mathrm{A}}$ & $0.68^{\mathrm{a}, \mathrm{A}}$ & $0.53^{\mathrm{a}, \mathrm{A}}$ & $0.66^{\mathrm{a}, \mathrm{A}}$ & $1.17^{\mathrm{b}}$ & $0.68^{\mathrm{a}}$ & $0.45^{\mathrm{a}}$ & 0.36 & $* * *$ & $* * *$ & $* * *$ \\
\hline & 2 & $3.87^{\mathrm{f}, \mathrm{B}}$ & $3.07^{\mathrm{d}, \mathrm{B}}$ & $4.14^{\mathrm{f}, \mathrm{B}}$ & $3.43^{\mathrm{e}, \mathrm{B}}$ & $3.05^{\mathrm{d}, \mathrm{B}}$ & $2.49^{\mathrm{c}, \mathrm{B}}$ & $1.06^{\mathrm{b}}$ & $1.05^{\mathrm{b}}$ & $0.68^{\mathrm{a}}$ & & & & \\
\hline \multirow[t]{2}{*}{$\mathrm{C} 20: 2$} & 1 & $0.34^{\mathrm{a}, \mathrm{A}}$ & $0.36^{\mathrm{a}, \mathrm{A}}$ & $0.44^{\mathrm{a}, \mathrm{b}, \mathrm{A}}$ & $0.39^{\mathrm{a}, \mathrm{A}}$ & $0.44^{\mathrm{a}, \mathrm{b}, \mathrm{A}}$ & $0.39^{\mathrm{a}, \mathrm{A}}$ & $0.65^{\mathrm{b}, \mathrm{A}}$ & $0.51^{\mathrm{a}, \mathrm{b}}$ & $0.49^{\mathrm{a}, \mathrm{b}}$ & 0.28 & $* * *$ & $* * *$ & $* * *$ \\
\hline & 2 & $2.93^{\mathrm{d}, \mathrm{e}, \mathrm{B}}$ & $2.91^{\mathrm{d}, \mathrm{e}, \mathrm{B}}$ & $3.09^{\mathrm{e}, \mathrm{B}}$ & $2.66^{\mathrm{b}, \mathrm{c}, \mathrm{B}}$ & $2.75^{\mathrm{c}, \mathrm{d}, \mathrm{B}}$ & $2.45^{\mathrm{b}, \mathrm{B}}$ & $0.38^{\mathrm{a}, \mathrm{B}}$ & $0.58^{\mathrm{a}}$ & $0.60^{\mathrm{a}}$ & & & & \\
\hline \multirow{2}{*}{ C20:3+4 } & 1 & $0^{\mathrm{A}}$ & $0^{\mathrm{A}}$ & $0^{\mathrm{A}}$ & $0^{\mathrm{A}}$ & $0^{\mathrm{A}}$ & $0^{\mathrm{A}}$ & 0 & 0 & 0 & 0.12 & $* * *$ & $* * *$ & $* * *$ \\
\hline & 2 & $1.37^{\mathrm{d}, \mathrm{B}}$ & $1.58^{e, \mathrm{~B}}$ & $1.50^{\mathrm{e}, \mathrm{B}}$ & $1.07^{\mathrm{b}, \mathrm{B}}$ & $1.32^{\mathrm{d}, \mathrm{B}}$ & $1.18^{\mathrm{c}, \mathrm{B}}$ & $0^{\mathrm{a}}$ & $0^{\mathrm{a}}$ & $0^{\mathrm{a}}$ & & & & \\
\hline \multirow[t]{2}{*}{ C20:5 } & 1 & $0^{\mathrm{A}}$ & $0^{\mathrm{A}}$ & $0^{\mathrm{A}}$ & $0^{\mathrm{A}}$ & $0^{\mathrm{A}}$ & $0^{\mathrm{A}}$ & 0 & 0 & 0 & 0.04 & $* * *$ & $* * *$ & $* * *$ \\
\hline & 2 & $0.38^{\mathrm{c}, \mathrm{B}}$ & $0.60^{\mathrm{f}, \mathrm{B}}$ & $0.42^{\mathrm{d}, \mathrm{B}}$ & $0.50^{\mathrm{e}, \mathrm{B}}$ & $0.30^{\mathrm{b}, \mathrm{B}}$ & $0.30^{\mathrm{b}, \mathrm{B}}$ & $0^{\mathrm{a}}$ & $0^{\mathrm{a}}$ & $0^{\mathrm{a}}$ & & & & \\
\hline \multirow{2}{*}{$\mathrm{C} 22: 6$} & 1 & $0^{\mathrm{A}}$ & $0^{\mathrm{A}}$ & $0^{\mathrm{A}}$ & $0^{\mathrm{A}}$ & $0^{\mathrm{A}}$ & $0^{\mathrm{A}}$ & 0 & 0 & 0 & 0.14 & $* * *$ & $* * *$ & $* * *$ \\
\hline & 2 & $1.47^{\mathrm{b}, \mathrm{B}}$ & $1.51^{\mathrm{b}, \mathrm{B}}$ & $1.43^{\mathrm{b}, \mathrm{B}}$ & $1.40^{\mathrm{b}, \mathrm{B}}$ & $1.49^{\mathrm{b}, \mathrm{B}}$ & $1.41^{\mathrm{b}, \mathrm{B}}$ & $0^{\mathrm{a}}$ & $0^{\mathrm{a}}$ & $0^{\mathrm{a}}$ & & & & \\
\hline \multirow{2}{*}{ Saturated } & 1 & $66.51^{\mathrm{a}, \mathrm{A}}$ & $67.84^{\mathrm{a}, \mathrm{b}, \mathrm{A}}$ & $66.86^{\mathrm{a}, \mathrm{A}}$ & $69.52^{\mathrm{a}, \mathrm{b}, \mathrm{A}}$ & $71.69^{\mathrm{b}, \mathrm{A}}$ & $65.97^{\mathrm{a}}$ & $69.86^{\mathrm{a}, \mathrm{b}, \mathrm{A}}$ & $68.85^{\mathrm{a}, \mathrm{b}}$ & $67.49^{\mathrm{a}, \mathrm{b}}$ & 5.07 & $* *$ & NS & $*$ \\
\hline & 2 & $61.93^{\mathrm{a}, \mathrm{b}, \mathrm{B}}$ & $62.68^{\mathrm{a}, \mathrm{b}, \mathrm{B}}$ & $60.33^{\mathrm{a}, \mathrm{B}}$ & $62.88^{\mathrm{a}, \mathrm{b}, \mathrm{B}}$ & $62.85^{\mathrm{a}, \mathrm{b}, \mathrm{B}}$ & $62.88^{\mathrm{a}, \mathrm{b}}$ & $64.57^{\mathrm{a}, \mathrm{b}, \mathrm{B}}$ & $66.42^{\mathrm{b}, \mathrm{c}}$ & $70.83^{\mathrm{c}}$ & & & & \\
\hline \multirow[t]{2}{*}{ Monounsaturated } & 1 & 30.11 & 30.17 & 30.84 & 27.95 & 25.75 & 31.69 & 25.58 & 27.36 & 28.50 & 6.20 & NS & NS & NS \\
\hline & 2 & 26.41 & 25.96 & 27.22 & 26.54 & 26.76 & 26.78 & 31.41 & 29.20 & 25.54 & & & & \\
\hline
\end{tabular}

a dithe same group, mean values affected by different letters are different $(P<0.05)$

${ }^{\mathrm{A}, \mathrm{B}}$ Within the same control, mean values affected by different letters are different $(P<0.05)$.

${ }^{1}$ The goats were hand-milked every day, and the production and composition of the milk were determined twice a week (controls).

${ }^{2}$ Residual standard deviation.

${ }^{3} P>0.05$.

$* P<0.05$.

$* * P<0.01$.

$* * * P<0.001$ 
ences were not significant $(P>0.05)$. Jenkins and Palmquist (1984) remarked that when a diet is supplemented with a protected fat in the form of calcium salts and food intake increases, with ruminal fermentation remaining unaltered, it would be worthwhile to investigate the ability of the animal in question to increase the amount of milk fat at the expense of that introduced into the diet. Similarly, Hermansen (1989) remarked that under such circumstances it is logical to consider that the greater energy intake received in the form of fat could lead to a greater production of milk fat. With respect to the protein content, it is normally considered that the introduction of a protected fat into the diet may lead to a fall in the concentration of milk protein, while yield values are not normally affected (Garnsworthy, 1996; Franklin et al., 1999). In the opinion of different authors, the fall in the quantity of milk protein that sometimes occurs when the diet is supplemented with fat is due to reduced food intake, which leads to a lesser degree of microbial protein synthesis in the rumen and consequently a reduced synthesis of protein in the mammary gland (Hermansen, 1990; Wu and Huber, 1994; Garnsworthy, 1996). With respect to the persistence of these effects after withdrawal of the supplement, we found no description in the literature of similar results. The only published data on the question are those of Pérez Hernández et al. (1986), who supplemented the diet of sheep with a protected fat in the form of calcium salts and obtained a higher concentration of fat in the milk. This increase disappeared when the supplementation was withdrawn, but was reestablished when fat was again introduced into the diet.

\section{Fatty Acids Profile of the Milk Fat}

The total concentration of saturated fatty acids (Table 3 ) varied between groups 1 and $2(P<0.05)$, and the interaction between the 2 factors was equally significant $(P<0.05)$. From the first to the fifth sampling times, the values corresponding to group 2 were statistically lower $(P<0.05)$ than those of group 1 . Within group 2 , the highest value, which was statistically different from the others $(P<0.05)$ corresponded to the final sampling time (sampling time 9). Within group 1, the values recorded were fairly homogeneous, although some significant differences $(P<0.05)$ were observed. The concentration of PUFA was affected by the supplementation of the diet with PUFA $(P<0.05)$. From the start of the trials until the sixth sampling time, inclusive, the values for group 2 were statistically greater than those for group $1(P<0.05)$. As normally occurs (Grummer, 1991; Franklin et al., 1999; Sanz Sampelayo et al., 2000), the change induced by the supplementation with the protected fat on the total concentration of saturated fatty acids was particularly the result of the lower concentration of stearic acid $(\mathrm{C} 18: 0)(P<0.05)$, and in the present case, too, of that of myristic acid $(\mathrm{C} 14: 0)(P<0.05)$, together with the higher proportion of the various PUFA $(P<0.05)$ except, in the present case, of linoleic acid (C18:2). The concentration of eicosatrienoic + eicosatetraenoic acids $(\mathrm{C} 20: 3+4)$, eicosapentaenoic acid (20:5), and docosahexaenoic acid (C22:6) were found to be zero at all the sampling times for the milk fat within the milk produced by the animals in group 1; these values were also zero in group 2 after the fat supplement was withdrawn. It is evident that the effects of the dietary fat supplement on the fatty acids profile of the milk fat did not persist when the supplement was withdrawn.

\section{CONCLUSIONS AND IMPLICATIONS}

When lactating goats were maintained under semiextensive breeding conditions, the dietary addition of a protected fat in the form of calcium salts, which was particularly rich in PUFA, produced an increase in milk production, together with higher fat and protein yields. These effects persisted after the dietary supplement was withdrawn. The added fat also produced significant changes in the fatty acids profile of the milk fat, reducing the concentration of saturated fatty acid and increasing that of the PUFA. In contrast to the effects on milk production and on the yields of constituents in milk, the effect on the fatty acid composition of the fat disappeared when the supplement is withdrawn from the diet. The data obtained are useful for determining how best to apply this dietary supplementation, depending on the desired effects.

\section{ACKNOWLEDGMENTS}

This study was supported financially by the Interministerial Commission of Science and Technology (Project ALI96-1024-C02-01), and by the Autonomic Andalucía Government. Spain. In addition, authors would like to thank the farmers who participated in the study, especially to Adela Reyes and Eduardo Gutiérrez.

\section{REFERENCES}

Albert, C. M., C. H. Henneken, C. J. O’Donnell, U. A. Ajain, V. J. Carey, W. C. Willett, J. N. Ruskin, and J. E. Manson. 1998. Fish consumption and risk of sudden cardiac death. J. Am. Med. Assoc. 279:23-28.

Ashes, J. R., B. D. Siebert, S. K. Gulati, A. Z. Cuthbertson, and T. W. Scott. 1992. Incorporation of n-3 fatty acids of fish oil into tissue and serum lipids of ruminants. Lipids 27:629-631.

Ashes, J. R., S. K. Gulati, and T. W. Scott. 1997. Potential to alter the content and composition of milk fat through nutrition. J. Dairy Sci. 80:2204-2212. 
Association of Official Analytical Chemists.1975. Official Methods of Analysis. 12th ed. AOAC, Washington, DC.

Boza, J., L. Pérez, and M. R. Sanz Sampelayo, inventors. 2000. Producto y procedimiento de obtención de una grasa protegida para incluir en las dietas de los rumiantes. Spain Pat. No. 2,136.536.

Brown-Crowder, I. E., S. Hart, and T. Sahlu. 1996. The use of bypass fat as an energy supplement for high producing does during early lactation. Proc. VI Int. Conference on Goats. Int. Academic Publishers, Beijing 2:643-645.

Daviglus, M. L., J. Stanler, A. J. Orencia, A. R. Dyer, K. Liu, P. Greenland, M. K. Walsh, D. Morris, and R. B. Shekelle. 1997. Fish consumption and the 30-year risk of fatal myocardial infarction. New. Engl. J. Med. 336:1046-1053.

Franklin, S. T., K. R., Martin, R. J. Baer, D. J. Schingoethe, and A. R. Hippen. 1999. Dietary marine algae (Schizochytrium sp.) increases concentrations of conjugated linoleic, docosahexaenoic and transvaccenic acids in milk of dairy cows. J. Nutr. 129:2048-2052.

Gagliostro, G. A., and Y. Chilliard. 1992. Utilización de lípidos protegidos en la nutrición de vacas lecheras. I. Efectos sobre la producción y la composición de la leche y sobre la ingestión de materia seca y energía. Rev. Arg. Prod. Anim. 12:1-15.

Garnsworthy, P. L. 1996. The effects on milk yield and composition of incorporating lactosa into the diet of dairy cows given protected fat. Anim. Sci. 62:1-3.

Giger, S., D. Sauvant, and J. Hervieu. 1987. Influence of the kind of compound feed on goat milk production and composition. Ann. Zootech. (Paris) 36:334-335.

Grummer, R. R. 1991. Effect of feed on the composition of milk fat. J. Dairy Sci. 74:3244-3257.

Hermansen, J. E. 1989. Feed intake, milk yield and milk composition by replacing unprotected fat by Ca-soaps for dairy cows. Anim. Feed Sci. Technol. 22:193-202.

Hermansen, J. E. 1990. Food intake, milk yield and live-weight gain of dairy cows given increased amounts of calcium-saponified fatty acids of palm acid oil. Anim. Prod. 50:11-18.

Hermansen, J. E., and P. Lund. 1990. Fatty acid composition and milk quality related to feeding Ca-saponified palm acid oil to different breeds of dairy cows. J. Dairy Res. 57:23-31.

Holter, J. B., H. H. Hayes, and W. E. Urbain, Jr. 1992. Energy balance and lactation response in Holstein cows supplemented with cottonseed with or without calcium soap. J. Dairy Sci. 74:1480-1494.

Jenkins, T. C., and D. L. Palmquist. 1984. Effect of fatty acids or calcium soaps on rumen and total nutrient digestibility of dairy rations. J. Dairy Sci. 67:978-986.
Martín-Hernández, M. C., M. Juárez, M. Ramos, and P. J. MartínÁlvarez. 1988. Composición de la leche de cabra de razas Murciana y Granadina. Anal. Bromatol. 40:237-248.

Morand-Fehr, P. 1997. Particularidades de la alimentación de cabras lecheras de alta producción: Estrategias a adoptar en ambientes mediterráneos o tropicales. In Proc. First Int. Meeting of the SEOC. Tenerife, Spain.

Ney, D. M. 1991. Potential for enhancing the nutritional properties of milk fat. J. Dairy Sci. 74:4002-4012.

Pearson, D. 1976. Laboratory Techniques in Food Analysis. Butterworths, London, UK.

Pérez-Hernández, M., J. J. Robinson, R. P. Aitken, and C. Fraser. 1986. The effect of dietary supplements of protected fat on the yield and fat concentration of ewe's milk and on lamb growth rate. Anim. Prod. 42:455. (Abstr.)

Sanz Sampelayo, M. R., L. Pérez, J. Boza, and L. Amigo. 1998. Forage of different physical forms in the diets of lactating Granadina gotas: Nutrient digestibility and milk production and composition. J. Dairy Sci. 81:492-498.

Sanz Sampelayo, M. R., J. J. Martín Alonso, D. Morón, L. Pérez, and J. Boza. 2000. Production of healthier goat milk. Use of a concentrate supplemented with a "protected" fat rich in PUFA. J. Physiol. Biochem. 56:231-236.

Sanz Sampelayo, M. R., L. Pérez, J. J. Martín Alonso, F. Gil Extremera, and J. Boza. 2002. Effects of concentrates with different contents of protected fat rich in PUFAs on the performance of lactating Granadina goats I. Feed intake, nutrient digestibility, $\mathrm{N}$ and energy utilisation for milk production. Small Rumin. Res. 43:133-139

SAS User's Guide: Statistics. Version 6 Edition. 1987. SAS Inst., Inc., Cary, NC.

Sauvant, D., J. Hervieu, S. Giger, F. Ternois, N. Mandran, and P. Morand-Fehr. 1987. Influence of dietary organic matter digestibility on goat nutrition and production at the onset of lactation. Ann. Zootech. (Paris) 36:335-336.

Schauff, D. J., J. H. Clark, and J. K. Drackley. 1992. Effects of feeding lactating dairy cows diets containing extruded soybeans and calcium salts of long-chain fatty acids. J. Dairy Sci. 75:3003-3019.

Steel, R. G. D., and J. H. Torrie. 1984. Principles and Procedures of Statistics: A Biometrical Approach. 2nd ed. McGraw-Hill Book Co., New York, NY.

Van Soest, P. J., J. B. Robertson, and B. A. Lewis. 1991. Methods for dietary fibre, neutral detergent fibre and non-starch polysaccharides in relation to animal nutrition. J. Dairy Sci. 74:35833597.

Wu, Z., and J. T. Huber. 1994. Relationship between dietary fat supplementation and milk protein concentration in lactating cows-a review. Livest. Prod. Sci. 39:141-155. 